Research Article

\title{
Mathematical Problem-Solving Ability in Differential Equation
}

\author{
Ari Suningsih *, Dewi Nopitasari \\ Mathematics Education of STKIP (Science Teacher Education) Muhammadiyah Pringsewu 35373, \\ Indonesia
}

Article history:

Submission August 2018

Revised August 2018

Accepted September 2018

${ }^{*}$ Corresponding author:

E-mail:

ari.suningsih@stkipmpringsewulpg.ac.id

\begin{abstract}
This study aims to describe the student's ability to solve math problems in the Differential Equation course in Polya's steps. This research is a descriptive study. The research subjects were the 6th-semester students of STKIP MPL for the 2018-2019 academic year. Data analysis used processed and prepared data, read the entire data, analyzed the detail, implemented the coding process, described themes, interpreted the data. The study found that the easy variable differential equation problems could be separated, 2 students understood the problem, 5 students initiated the solution, 4 students completed through the plan, 2 students checked again, 2 students completed through the plan, no students checked again.
\end{abstract}

Keywords: Problem solving, polya, differential equation

\section{Introduction}

Education is a normative relationship between individuals and values. It is seen from the process point of view that education is a process to influence students, so they can adapt as well as possible to their environment and cause possible changes in themselves, and function as their competence in community life.

Mathematics is basic science, so mathematics has an important role in various disciplines. Mathematics should be studied systematically and regularly and must be presented by good structure and adapted to the student's intellectual development and the prerequisite abilities they have. Mathematics learning tends to target curriculum achievement, meanwhile, students tend to memorize mathematical concepts provided by educators without understanding their intentions and contents [1].

A differential equation is an equation that contains derivatives, at least one derivative of an unknown function. The term of Differential Equation is usually abbreviated as PD. If a PD contains one or more derivatives of a variable against other variables, the first variable is called the dependent variable, while the second variable is called the independent variable.
From the interview with fourth-semester Mathematics students, the 2017-2018 academic year, they considered that the Differential Equation course is quite difficult. In solving a problem, students do not fully understand the steps that must be used to solve the problem. 29 students who worked on Differential equations problems were still inaccurate in solving problems.

The questions given to students consisted of 4 items with code A and B, the researcher took a sample question with code B. All students were able to answer question number 1 correctly because the questions given were easy, namely giving examples PD forms with order 3 and degree 1 . Question number 2 compiled the PD from $y=A e^{-2 x}+B x e^{-2 x}$, all students working on the question got some difficulty using the steps for solving PD questions. In question number 3 was to determine the general answer of the PD from $\left(4 x^{2}+y^{2}\right) d x-$ $(2 x y) d y=0$. In this question, some students do it correctly, but some students did it incorrectly. The results showed that there were differences in integrated cognitive conflict learning with soft skills learning and cognitive conflict learning that were not integrated with soft

How to cite:

Suningsih A, Nopitasari D (2020) Mathematical problem-solving ability in differential equation. Basic and Applied Educational Research Journal 1 (1): 37 - 40. doi: 10.11594/baerj.01.01.05 
skills mathematical problem-solving abilities in differential equations courses [2] Students with high initial abilities do not have fluent thinking, but these students show new thinking that qualifies as Creative Thinking Ability Level, (2) Students with current prior knowledge have fluency in thinking, but do not have the flexibility and novelty of thinking that meets the requirements as the level of creative thinking skills, (3) Students with low initial knowledge but have elegance, fluency, and novelty thinking which get into the criteria [3]. Female students in mathematical communication skills for solving differential equation problems are better than male students [3]. Students are more independent and actively involved in learning differential equations by applying to the scaffold [4].

Students did not understand what is known and what is being asked on the question, a student could not do the question correctly. Therefore, students were not fully able to solve the problem correctly. Problem-solving is an effort made to solve the problems found. Talking about problem-solving cannot be separated from the main character, namely George Polya. According to Polya, there are four steps in solving the problem, there are: (1) understanding the problem, (2) planning the solution, (3) solving the problem according to the second step, and (4) checking the results obtained. Students should use the Polya steps as described above to easily solve the problems.

\section{Material and Methods}

Data collection techniques used in this research were including efforts to limit research, collected information through observation and interviews, both structured and unstructured, documentation, visual materials, and efforts to design protocols for recording information [5]. Data collection procedures in qualitative research involve four types of strategies, namely:

\section{Observation}

Through the observations, researchers directly went to the field to observe the behavior and activities of individuals at the research location. In that way, researchers could record both in a structured and semi-structured way.

\section{Interview}

Interviews are conducted with students who were research informants, researchers did face-to-face interviews with participants, interview by telephone, or engage in interviews with certain groups.

\section{Documentation}

During the research process, researchers also collected qualitative documents. These documents could be public documents (such as newspapers, papers) or private documents (such as diaries, letters, e-mails)

\section{Audio-visual materials}

This data could be in the form of photos, art objects, videotapes, or any kind of sound. The validity of the data is vital so that the result data can be trusted and scientifically accounted for. Checking the validity of data is one of the steps to reduce errors in the research data process which will certainly affect the final result of a study. Sugiyono [6] said that source triangulation used to test the credibility of the data is done by checking the obtained data through several sources.

According to Creswell [5], data analysis is a continuous process that requires continuous reflection on data, asking analytical questions, and writing short notes throughout the research. Below are six steps in analyzing data, namely: a) Processing and preparing data, b) Reading the whole data, c) Analyzing more detail by coding the data, d) Application of the coding process, e) Showing descriptions and themes, f) Interpreting the data.

\section{Results and Discussion}

Based on the results, 10 research subjects still had difficulties in problem-solving ability test questions. In the first question, 3 subjects were able to understand the given problem, they could explain what was known and what was asked. In the plan completion, 3 subjects could plan the completion well. Meanwhile, subjects who had not planned the completion well were seen on their working on following the steps that had been given previously with almost the same questions. In solving the problem, there was 1 subject solved according to the 
previous plan. The subject operated the solution by directly integrating the equation and did not change it into an easy differential equation. In re-checking, no subject was able to check the answers that had been completed which saw whether the steps used were correct or not.

In the second question, there were 4 subjects were able to understand the problem. The subject could explain what was known and what was asked. In planning the solution, 4 subjects can plan the solution well by changing the equation to be equal to 0 . In solving the problem, 2 subjects could solve it well by making the equation easy to PD so it made it easier for the subject to operate and find the integral value forget general PD answers. In re-checking, no subject checked the answers that had been completed to see whether the steps used are correct or not. In the third question, 5 subjects could understand the problem in that subject.

The subject could explain what was known and what was being asked. In planning the solution, 4 subjects were able to plan well, because the questions were known to be homogeneous, the steps used are a sample of $y$ and $d y$ first. In solving the problem, there was 1 subject who could solve according to the plan, the step used was to put the $y$ and $d y$ value and into the initial equation, then made it into an easy PD to make it easier for the calculations then integrated the equation and got the result of the integral. In re-checking, no subject checked the answers that had been completed to see whether the steps used were correct or not. In the fourth question, in understanding the problem 6 subjects could understand the questions given. The subject could explain what was known and what was asked. In planning the solution, 5 subjects could plan the solution well, because the problem was definite, the first step was the derivative of the two known equations. In solving the problem, 4 subjects completed the steps that have been planned, then the subject looked for the derivative value of the initial equations, after the results got were congruent, the general answer of PD would be obtained. In rechecking, there was only 1 subject who checked the answers that had been completed to see whether the steps used were correct or not.

Based on the description results above, it can be seen that students had difficulties in the problem-solving ability test on the first level differential equation material. One of the factors that affected students was the student's lack of basic skills in mathematical operations, especially in differential equations courses. This is supported by Ayu Yarmayani [7] research stated that the ability to solve mathematical problems is one of the abilities that students must have, because problem-solving provides great benefits to students in seeing the relevance of mathematics with other subjects, and in real life.

\section{Conclusion}

The data analysis and discussion obtained the conclusion that the problem-solving ability of students in first-level differential equation test of 6th-semester students of the Mathematics Education Study Program of the Muhammadiyah Pringsewu Lampung School of Education and Education (STKIP MPL) in the 20182019 academic year was still lacking in the sense that they had not used appropriate and good solving steps. In question number 1 about easy differential equations with separable variables, the results were 2 students could understand the problem, 5 students could plan solutions, 4 students could complete according to plan, and 2 students could check again.

In question number 2 about differential equations with separable variables, the results were 2 students could understand the problem, 4 students could plan solutions, 3 students could complete according to plan, and there was no student checked again. In question number 3 about homogeneous differential equations, the results were 3 subjects could understand the problem, 4 students could plan solutions, 2 students could complete according to plan, and there was no student checked again. In question number 4 about definite differential equations, the results were 5 students could understand the problem, 5 students could plan solutions, 4 subjects could complete according to plan, and 3 students could check again. 


\section{Acknowledgment}

The authors say thanks to Mathematics Education of STKIP (Science Teacher Education) Muhammadiyah Pringsewu, Lampung for supporting and facilitating this research.

\section{References}

1. Utami R (2013) Model pembelajaran berbasis masalah dengan langkah penyelesaian berdasarkan polya dan krulik-rudnick ditinjau dari kreativitas siswa. Jurnal Ilmiah Pendidikan Matematika 1 (1): 82-98.

2. Marliani N (2015) Kemampuan pemecahan masalah matematis pada mata kuliah persamaan diferensial dilihat dari pembelajaran konflik kognitif yang terintegrasi dengan soft skill. Formatif: Jurnal Ilmiah Pendidikan MIPA 5(2): 1-10.
3. Murtafiah W (2017) Profil kemampuan berpikir kreatif mahasiswa dalam mengajukan masalah persamaan diferensial. JIPM (Jurnal Ilmiah Pendidikan Matematika) 5(2): 73-81.

4. Sulistyorini Y (2017) Analisis kesalahan dan scaffolding dalam penyelesaian persamaan diferensial. Kalamatika: Jurnal Pendidikan Matematika 2(1): 91-104.

5. Creswell, JW. (2015). Research Design Pendekatan Kualitatif, Kuantitatif, dan Mixed. Yogyakarta: Pustaka Pelajar.

6. Sugiyono (2011) Metode Penelitian Pendidikan Pendekatan Kuantitatif, Kualitatif, dan R\&D. Bandung: Alfabeta.

7. Yarmayani A (2016) Analisis kemampuan pemecahan masalah matematis siswa kelas XI MIPA SMA Negeri 1 Kota Jambi. Jurnal Ilmiah DIKDAYA 6 (2): 12-19. 